\title{
Training of school directors for the School Health Program:
}

\section{a research-action}

\author{
VERAS, Karlla da Conceição Bezerra Brito (Fortaleza, Ceará, Brasil) ${ }^{1 *}$ \\ FERREIRA, Heraldo Simões (Fortaleza, Ceará, Brasil) $)^{2 *}$ \\ LOURINHO, Lídia Andrade (Fortaleza, Ceará, Brasil) 3 $^{* * *}$ \\ 1 Universidade Estadual do Ceará, Programa de Pós-Graduação em Cuidados Clínicos em \\ Enfermagem e Saúde, Doutorado em Cuidados Clínicos em Enfermagem e Saúde \\ '2Universidade Estadual do Ceará, Programa de Pós-Graduação em Educação, \\ Curso de Mestrado e Doutorado em Educação \\ ${ }^{3}$ Universidade Estadual do Ceará, Programa de Pós-Graduação em Saúde Coletiva, \\ Curso de Mestrado Profissional Ensino na Saúde \\ ORCID ID: https://orcid.org/0000-0001-7464-1992* \\ ORCID ID: https://orcid.org/0000-0003-1999-7982* \\ ORCID ID: https://orcid.org/0000-0002-5883-9007
}

\begin{abstract}
The objective was to analyze a training process on the characteristics of the Health at School Program with school principals. The study was carried out with an action research in a qualitative approach. The study scenario was the municipality of São Benedito, Ceará. The research participants were ten public school principals. In phase I, after analyzing the responses, it was diagnosed that $90 \%$ of the directors knew about the program. In phase II, an action was taken in the format of training on the Health at School Program. In phase III, there was a group interview with the directors participating in the training, in which they reported that the training was excellent, practical, objective and dynamic. The research results indicated that the training on the mentioned program contributes significantly to the transformation of professional practices, constituting itself as an essential strategy for the improvement of the actions of the Health at School Program.
\end{abstract}

\section{Keywords}

Health at school. Schooling. Health education.

\section{Formação de diretores escolares para o Programa Saúde na Escola: uma pesquisa-ação}

\begin{abstract}
Resumo
Objetivou-se analisar um processo de formação sobre as características do Programa Saúde na Escola com diretores escolares. O estudo foi realizado com uma pesquisa-ação em abordagem qualitativa. O cenário de estudo foi o município de São Benedito, Ceará. Os participantes da pesquisa foram dez diretores de escolas públicas. Na fase I, diagnosticou-se, após a análise das respostas, que $90 \%$ dos diretores conheciam a existência do referido programa. $\mathrm{Na}$ fase II, empreendeu-se uma ação no formato de formação sobre o Programa Saúde na Escola. Na fase III, ocorreu a entrevista em grupo com os diretores participantes da formação, em que relataram que a formação foi excelente, prática, objetiva e dinâmica. Os resultados da pesquisa indicaram que a formação sobre o mencionado programa contribui expressivamente para a
\end{abstract}


transformação das práticas profissionais, constituindo-se como uma estratégia essencial para o aprimoramento das ações do Programa Saúde na Escola.

\title{
Palavras-chave
}

Saúde na escola. Educação escolar. Educação para a saúde.

\section{Formación de directores escolares para el Programa Salud en la Escuela: una investigación-acción}

\begin{abstract}
Resumen
Se objetivó analizar un proceso de capacitación sobre las características del Programa Salud en la Escuela con directores de escuelas. El estudio se realizó cono una investigación de acción en un enfoque cualitativo. El escenario de estudio fue el municipio de São Benedito, Ceará. Los participantes de la investigación fueron diez directores de escuelas públicas. En la fase I, se diagnosticó, después de analizar las respuestas, que el $90 \%$ de los directores conocían el programa. En la fase II, se tomó una acción en el formato de capacitación sobre el Programa Salud en la Escuela. En la fase III, hubo una entrevista grupal con los directores que participaron en la capacitación, en la cual informaron que la capacitación fue excelente, práctica, objetiva y dinámica. Los resultados de la investigación indicaron que la capacitación en el programa mencionado contribuye significativamente a la transformación de las prácticas profesionales, constituyéndose como una estrategia esencial para la mejora de las acciones del Programa Salud en la Escuela.
\end{abstract}

\section{Palabras clave}

Salud en la escuela. Educación escolar. Educación para la salud.

\section{Introduction}

There is growing interest in the theme of health within school populations. Therefore, schools became privileged spaces to carry out health education strategies, understood as a tool to achieve the health of students.

The school environment is a favorable space for the development of educational practices aimed at promotion and prevention in health, understanding that these are related to individuals' quality of life and that this scenario, since it is an environment that shapes knowledge and opinions, should discuss this theme in order to educate critical people (FERREIRA, 2012).

Thus, schools are one of the places that articulate different sectors of society, where programs for the promotion of and education on health can be developed 
(FIALHO; SANTANA; BRANDENBURG, 2015). It is the ideal place to carry out health actions, working on the needs of each student.

Consequently, there was the need to implement the Health in School Program (PSE, in Portuguese). The PSE was implemented in 2007, through presidential decree n. 6.286/2007, consisting of a partnership between the Ministry of Education and the Ministry of Health, constituting an intersectional policy which aims to contribute positively for the training of health and education professionals and students, in addition to enabling prevention, promotion and attention to health (BRASIL, 2007).

Therefore, PSE predicts actions of education concerning health, prevention, treatment and maintaining health for students from public schools, in addition to the qualification of professionals concerned with actions related to the PSE. The program highlights the need to discuss health themes in the classroom, using spontaneous and playful student participation. Thus, there is the need for a permanent training process with the professionals who work with the program, due to constant changes in the routine of services, improving the quality of assistance toward the school community.

Based on that principle, the reflections presented here raised the following questions: Is a training process about PSE characteristics, with school principals, effective in qualifying them for practice? What is the study participants' knowledge level when it comes to PSE?

Therefore, this research aims to analyze a training process concerning the characteristics of PSE with school principals in the municipality of São Benedito - Ceará. In this perspective, professionals who are new to PSE must be qualified to carry out the program activities.

\section{Methodology}

This study is an action research with a qualitative approach. Thiollent (2011) defends the use of action research in the Education field, because it proposes that researchers commit to popular causes, seeking solutions or, at least, seeking to elucidate problems.

Concerning qualitative research, Minayo (2010) describes that its function is to investigate subjects in depth, evaluating emotional and intentional factors implicit in 
interviewees' positions and behaviors, thus revealing little-known social processes, related to particular groups, and supporting, throughout the investigation, the construction of new discussions, review and creation of concepts and categories.

The study took place in the municipality of São Benedito - Ceará. Out of 51 schools registered in the city's PSE, 10 were selected to be part of the research, because these education institutions are in the territory of principals who will begin working with PSE, an important factor for those participating in the research.

Data collection in action research, as established by Thiollent (2011), stipulates the following phases: diagnosis, planning/action and evaluation. In the first phase of the research, participants were verified and a diagnosis about PSE knowledge was carried out with the professionals. For that end, we used a questionnaire.

In the second phase of data collection, planning and action were carried out. Action planning took place based on data collected in the first phase. The action itself consisted of training on PSE, with a course load of 10 hours. In this phase, the collection technique was participant observation, using an observation script in which the researcher and the professionals working with PSE acted in a cooperative and participant manner. A field diary was also used to enable the systematization of information.

In the third phase of data collection, we carried out the evaluation of principals participating in the research through a group interview, when we also evaluated the training and its efficacy in the practice of PSE.

To analyze the data concerning the assessment of participants' academic and professional profile and the diagnosis of PSE knowledge, in the first phase, interpretative data analysis was used. In the second phase, a subjective interpretation of data observed in the field diary was performed. The analysis in phase three was carried out through the thematic analysis of Minayo (2010), which is defined as the discovery of meaning nucleuses, which consist of communication about the frequency or presence of a meaning for the object being analyzed and is comprised of pre-analysis, exploration of all available material, and categorization through themes in the participants' speech.

All the information was consolidated through the activities that were carried out and recorded in the field diary. After recording the interviews, they were fully transcribed and archived in order to ground later categorization, following the thematic analysis technique according to Minayo (2010). 
This experience is part of a larger research called "Professional training for the Health in School Program: an action research", submitted to the Committee of Ethics and Research at UECE, CAAE: 7139117.0.0000.5534. An informed consent form was drafted for the research participants. And the research adopted Resolution n. 466/12 of the National Health Council (CNS, in Portuguese), which guarantees protection for human beings who participate in scientific research, respecting their dignity.

\section{Results and discussions}

\subsection{Phase I- Diagnosis of school principals' knowledge level concerning PSE}

In this phase, the obtained information was collected through a questionnaire answered by 10 school principals, in order to assess their knowledge concerning the PSE. The questions concerned PSE: 1) Knowledge about PSE; 2) PSE objectives; 3) Actions carried out in PSE; 4) Professionals responsible for PSE execution; 5) The role of professionals in PSE activity.

\subsubsection{Participants' profile}

This study had the participation of 10 public school principals who are beginning their activities in the PSE of selected schools. The professionals' profile is shown in Graph 1, and $100 \%$ of principals were female.

Graph 1 - Participants by gender

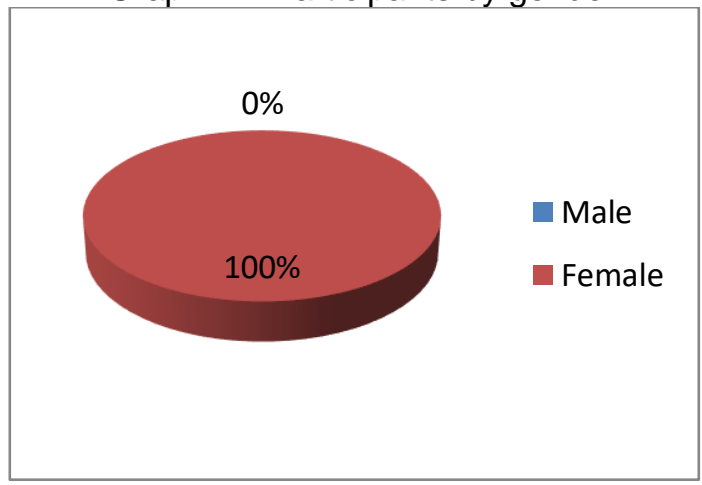

Source: Own elaboration (2017).
Graph 2 - Participants by age

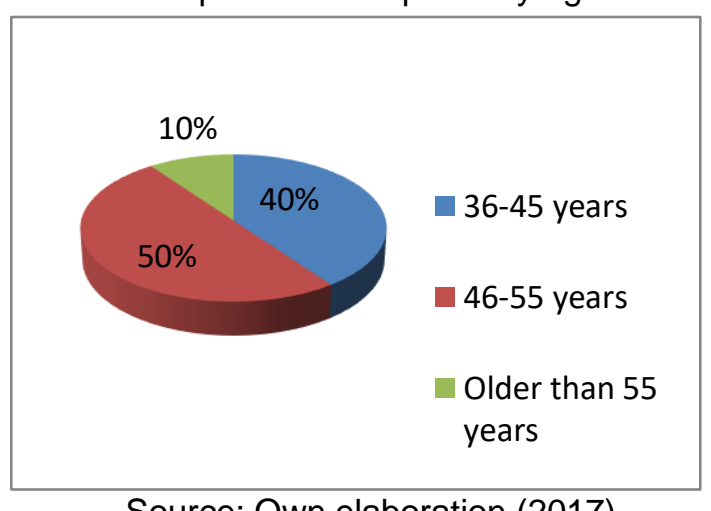

Source: Own elaboration (2017). 


\subsubsection{School principals' knowledge of the existence of PSE}

The first question in the questionnaire concerned the professionals' knowledge about the existence of PSE. The professionals' answers were objective and direct. It can be observed in the answers (Graph 3 ) that $90 \%$ of principals (09) know that PSE exists. A minority, $10 \%$ (one principal), reports having heard of PSE.

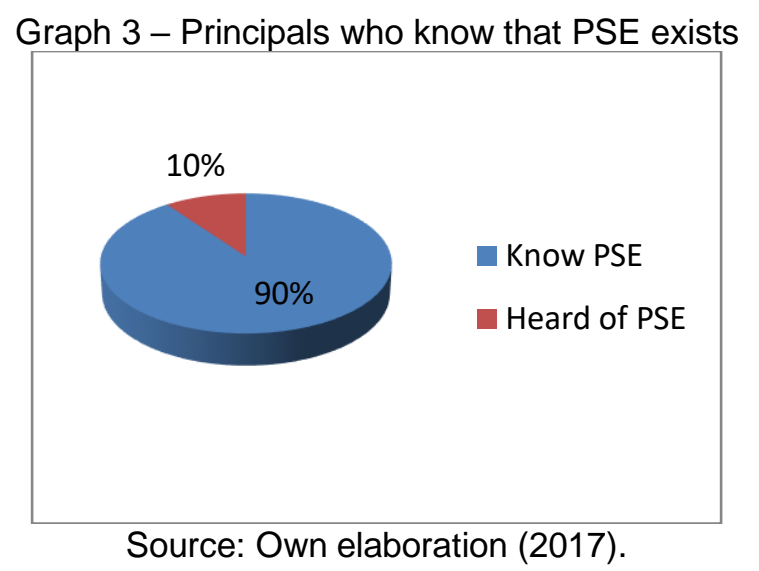

It is noticeable that most principals know that the program exists. This is due to the fact that the program exists since 2007. The year of 2013 was marked by the universalization of PSE and expansion of actions of promotion and attention to health.

\subsubsection{School principals' knowledge about the objectives of PSE}

The second item of the questionnaire collected information from the professionals about their knowledge regarding the objectives of PSE. As can be noticed in the following considerations, some principals have a notion of the objectives of PSE, generating a variety of discursive answers. Others notice particularities that, in fact, characterize PSE, but still in a fragmented way, contemplating small dimensions of the program. According to some principals:

PSE has the objective of making a partnership between health and education, seeking improvements in students' quality of life. (PRINCIPAL 1, our translation). 
PSE seeks to promote the improvement of health in children and teenagers and gives access to students to specialized assistance that they often don't get in their everyday life. (PRINCIPAL 2, our translation).

The objective of PSE is to assist the school community in its territory, with better quality. (PRINCIPAL 4, our translation).

It can be noticed that some reports are still distant from the objectives of PSE, since the principals see it as something that simply informs or carries out procedures, and not as a space for the construction of knowledge and promotion of health. The objective of PSE is to contribute to the students' integral education, through actions of integral health (prevention, promotion and attention to health, access to the different levels of attention in public health), aiming at the confrontation of vulnerabilities that risk the full development of children and teenagers in Brazilian public schools (BRASIL, 2009b; FERREIRA et al., 2014). The questions answered by professionals about the objectives of PSE had vague answers, showing that professionals don't know the program's real objectives.

\subsubsection{Actions carried out in PSE}

As a way to understand if principals know the actions that must be carried out in the program, the fourth item in the questionnaire asks professionals about the actions of PSE. As can be seen in the following reports, participants partially describe notions of actions encompassed by PSE:

\footnotetext{
In the school visits, health professionals evaluate students, work with disease prevention and promote lectures with information about health and well-being for students. (PRINCIPAL 1, our translation).

[...] it carries out with students weight control and evaluation of blood pressure. (PRINCIPAL 5, our translation).

[...] The health professionals get students physical exams and actions of dental care. (PRINCIPAL 9, our translation).
}

The PSE components, listed and contemplated in its national document, are: a) Evaluation of health conditions of children, teenagers and young adults who are in public school; b) Promotion of health and prevention activities; c) Permanent education and qualification of education and youth health professionals; d) Monitoring and evaluation of 
students' health; e) Monitoring and evaluation of the program (BRASIL, 2015b, 2015c, 2016).

Therefore, for the implementation of education actions, the involvement of all actors is a unique condition for the unrestricted exercise of health, however, in the context involving PSE, one of the challenges to implement actions is the qualification of school professionals to work with health education.

\subsubsection{Professionals responsible for the execution of PSE}

The fifth item of the questionnaire aimed to verify the knowledge of all involved regarding which professionals are responsible for the execution of PSE activities. Seeking to understand, it is possible to notice in the answers the importance of this investigation, presenting speech from four school principals, who consider that PSE actions are only the responsibility of health professionals.

[...] Nurses and nursing technicians are the professionals who should carry out the program's activities. (PRINCIPAL 5, our translation).

[...] Psychologist, speech therapist, occupational therapist, nutritionist and physical therapist should carry out the PSE actions. (PRINCIPAL 6, our translation).

[...] Nurses and community health agents are responsible to carry out PSE actions. (PRINCIPAL 8, our translation).

[...] Nurse, health agent, doctor, nutritionist, dentist and the team from the Family Health Support Center (NASF). (PRINCIPAL 2, our translation).

Based on the analysis of some aforementioned reports by school principals, it is possible to notice that they believe that PSE only takes place when health professionals go to the school and that they aren't also required to continue, within their acting and knowledge fields, the actions contemplated by the program. Thus, we consider a lack of teamwork, actually integrated with the school.

Continuing the reports, two principals included school professionals in the execution of PSE actions, according to the following statements: 
The professionals who should take part in the execution of PSE actions are: professionals from the basic health unit, NASF team, school principals and coordinators. (PRINCIPAL 1, our translation).

Should participate in PSE actions all professionals involved with health and education in the municipality. After all it is a partnership for the improvement of the quality of life of students. The professionals are: Principals, coordinators, teachers and cafeteria workers. Nurses, dentists, doctors and community health agents from the basic health unit. (PRINCIPAL 4, our translation).

Besides the participation of teaching staff and school management in the execution of PSE, the other members of the school community can also be involved, that is, administrative assistants, secretaries, cafeteria workers, cleaning staff, families and people from the community (BRASIL, 2011).

Thus, principals and other school professionals, with the support of health, will have the security to approach daily themes that help in the prevention of diseases and in the promotion of health, promoting health and quality of life for students (SANTOS; FERREIRA; SIMÕES, 2016).

\subsection{Phase II - Planning/Action: Training of school principals for PSE}

The action of phase II consisted of a training action with the school principals. In summary, the activities that elucidated the training proposed here were drafted based on the results from the diagnosis of principals' knowledge level concerning PSE (phase I), which grounded a description of the knowledge held by the professionals, allowing the intervention to act on enhancing the professionals' doubts. Thus, the training was carried out after the first phase, when the researcher analyzed questionnaire answers, diagnosed the principals' knowledge and prepared the training.

Therefore, in order to execute the training, the subjects discussed were based on materials published about PSE in the Ministry of Health's Virtual Health Library: The PSE Manager's Notebook (2015); PSE Step by Step - weaving paths of intersectionality (2011); Activity Suggestions Guide: Health in School Week (2013); Basic attention notebook: Health in School (2009); Interministerial Ordinance n. 1.055, from April 25th 2017; Visual-Manual Acuity Orientation Screening (2008); PSE Thematic Notebooks: Eye Health (2016); Thematic Notebook: Verifying Vaccination Situation - 
Preliminary Version (2015); Thematic Notebook: Corporal practices, physical activity and leisure - Preliminary version (2015).

The items observed in phase II during the execution of the training activity with the professionals were: involvement, motivation, doubts about PSE, teamwork/interaction, ability to construct knowledge and principals' interest on the training. In this perspective, the training activity took place in the auditorium at the Municipal Secretariat of Health of São Benedito - CE, during one day (morning and afternoon) in September 2017, comprising a total workload of 10 hours. It was taught by the research author, embracing the challenge to draft and develop an exciting and motivating training.

Table 1 - Program of the school principal training for PSE

\begin{tabular}{|c|c|}
\hline Morning & Afternoon \\
\hline $\begin{array}{l}\text { 07h - Welcoming and integration of school } \\
\text { principals. }\end{array}$ & $\begin{array}{l}\text { 13h - Health in School Program: Brief History of } \\
\text { PSE implementation in Brazil and in the } \\
\text { municipality of São Benedito - CE; PSE guidelines } \\
\text { and objectives; Implementation, execution and } \\
\text { management of PSE. }\end{array}$ \\
\hline $\begin{array}{l}\text { 07h15 }- \text { Opening ceremony. } \\
\text { exposition: principles of collective health. }\end{array}$ & 14h15 - Thematic fields of actions within PSE. \\
\hline 08h - Dialogued exposition: health promotion. & 15h - Break. \\
\hline $\begin{array}{l}\mathbf{0 8 h} 40 \text { - Dialogued exposition: humanization and } \\
\text { care in school health. }\end{array}$ & $\begin{array}{l}\text { 15h15 - Students' eye health and benefits of } \\
\text { continued service. }\end{array}$ \\
\hline 09h30-Break. & $\begin{array}{l}15 \mathrm{~h} 40 \text { - Protecting and caring for the teenager's } \\
\text { health in the PSE context. }\end{array}$ \\
\hline $\begin{array}{l}\text { 09h50 - Dialogued exposition: Integrality as a } \\
\text { coordinating principle in SUS and as guiding axis } \\
\text { in actions for health education. }\end{array}$ & $\begin{array}{l}\text { 16h - Weaknesses in the execution of PSE } \\
\text { actions. }\end{array}$ \\
\hline $\begin{array}{l}\text { 11h - Dialogued exposition: Intersectionality in } \\
\text { establishing PSE. }\end{array}$ & $\begin{array}{l}\text { 16h30 - Highlighting good experiences of PSE in } \\
\text { Brazil. Group activity: Dialogued reading of } \\
\text { scientific articles with PSE experiences in other } \\
\text { cities. }\end{array}$ \\
\hline 12h - Lunch break. & 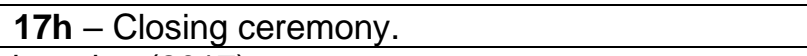 \\
\hline
\end{tabular}
Source: Own elaboration (2017).

During the training, the school principals had many doubts about the themes discussed in PSE. These difficulties arose because these professionals don't work in the Health field, thus consisting of a relatively new and challenging action for them concerning the construction of professional autonomy for the development of the new activity (BEGO, 2016). 
In the study by Zancha et al. (2013), the authors bring this approach when they affirm that the teaching of the health theme has been a difficulty for the education professionals in order to guarantee an effective and transforming learning of habits and attitudes of life to the students. Thus, they agree that it's not just about having the knowledge in order to teach, but that the approach itself and the doubts generated require adequate preparation for these professionals.

Other questions were asked about planning for actions of health professionals along with school professionals; how would they combine all the actions that had to be executed? However, one of the biggest doubts the training participants had was actually about understanding how PSE works and the articulations between the Education and Health fields in practice. There were also many doubts related to the program funding and the system for monitoring actions (system for the inclusion of health data E-SUS in basic attention and time to input information).

Another important doubt was about the visual acuity test, using the Snellen test. The principals argued that only ophthalmologists or nurses should carry out the test. However, according to the Ministry of Health guidelines, any health or education professional qualified to execute a Snellen test can do it. According to Ordinance n. 254, from July 24th 2009, visual acuity screening can be carried out by Health and Education professionals.

The principals also showed more awareness of the importance of carrying out actions with health professionals, the objectives of PSE and their implications, as well as recognized their role and responsibility in this scenario, achieving interdisciplinary perspective.

In this sense, the interaction and knowledge exchange during training also enabled the strengthening of the professionals as social subjects and increased awareness, because, by interacting with other professionals who experience similar situations, these individuals' representations were acknowledged or transformed.

Concerning the knowledge acquired, we evidenced that the educational intervention resulted in elucidation of the possibilities in their workspace to execute the program's activities. Findings also indicate that there was a collective learning process among the professionals. 
Ceccim (2005) relates that, through education and permanent training, individuals are actives actors in training and work scenes (products and producers of the scenes, in the act). The acted events produce differences, affect, modify, producing disturbances in the subject, placing people in permanent production. Permanent is here and now, facing real problems, real people and real teams.

From this point of view, education and knowledge have great interrelation, since educational practice consists of a situation of knowledge made practice and is political because there is reflection in this practice (FREIRE, 2011). In this perspective, generally, the repercussions of the training activity were positive, since it encouraged the acknowledgement of the importance of executing PSE actions in practice at work.

\subsection{Phase III - Group interview with school principals}

The third phase of this research consisted of a group interview with the professionals who participated in the training, as a way to evaluate the contribution of the training process in the participants' practice. A tool was used to guide the progress of the group interview.

In this moment, the 10 school principals were reunited for the group interview, which took place one month after the training, time used by the professionals to execute some PSE activities in their territories, applying the theory they learned during training in their everyday PSE practice. This time was proposed and agreed upon between the principals and the researcher.

The professionals recorded their opinions in the group, answering individually or complementing other participants' answers, respecting each other's right to speak and weaving a collective discussion. The interviews were recorded and later transcribed.

The results from phase III were divided in six categories, which were defined according to the group instrument tool, which grounded the researcher's discussion with the professionals. The six categories were: Evaluation of the training activity about PSE; School principals' knowledge of PSE, before and after training; Contribution of training to their PSE professional practice; Contribution of training to personal growth; Contribution of training to the relationship with colleagues and PSE users; and Suggestions for the training to be more resolute in what it proposes. 
3.3.1 Evaluation of the training activity about PSE

As can be noticed in the following considerations, school principals reported that training was relevant to give direction about how to develop PSE activities and that the professionals always need to seek more qualification and improve the knowledge that they already have. Thus, we present some reports:

The training methodology was excellent, as well as the material and the teacher, where it awoke in us involvement and learning about PSE, guiding us in the execution of PSE activities. But it was too short, I wish we had more moments like that. (PRINCIPAL 7, our translation).

Very good, practical and easy to understand. Throughout the training, theory and practice were together. I would like trainings about PSE to be offered more often and that they reached all principals, not only a few. Since it's a very rich learning moment, everyone should participate. (PRINCIPAL 6, our translation).

With the training I got to know and experience PSE. It was taught clearly. The teacher showed security when discussing the subject, using dynamic methodology, quality materials and a welcoming environment, fostering better learning. (PRINCIPAL 9, our translation).

In the beginning of the training activity, we needed actions that stimulated the professionals' curiosity, so that they could seek more and more information about the program and the conduction of executed strategies, elucidating doubts about the program and the attributions of each actor involved.

Ramos et al. (2013) describe training as an important space for dialogue, where people express themselves, listen to others and to themselves, stimulating individuals' autonomy through the exchange of information and reflection for action, mediating reciprocal learning and/or associating abilities, because all participants have equal power over the territories they discuss.

The school principals, in their reports, mentioned that the training was excellent, practical, objective, dynamic and easy to understand, guiding the execution of PSE activities and always connecting theory and practice. There were accessible resources, quality material, adequate space that met their needs and welcoming environment. They acknowledged that they need qualification to improve their work and that other trainings about PSE could be carried out, but they should reach all principals from schools in the municipality. 


\subsubsection{School principals' knowledge of PSE, before and after training}

In the second interview item, the professionals involved in the training were asked to comment on their knowledge about PSE before and after the training activity. Some comments from the principals are cited below:

Before the training, I had heard of PSE, but I thought the functions of the program were only for professionals in the health field. Today, after training, I understand that in order to execute actions, it can't be isolated work, but teamwork, as a partnership. (PRINCIPAL 2, our translation).

Before training, I had no knowledge about PSE and also didn't know its importance in schools. But after the training, I realized the advantages and benefits of the program for students in municipal and state schools. (PRINCIPAL 4 , our translation).

Before training I had no knowledge about the program, how it worked, and about the importance of the school's participation and collaboration. After participating in the training, I started seeing the importance of the work of the entire team in another light, now I know that this work isn't just the responsibility of the health team, but also of the professionals who are in the school, since the program is a partnership between health and education. (PRINCIPAL 10, our translation).

According to Fernandes (2008), the learning process can be characterized as reconstructive: it goes beyond technical updates and appeals to a deep confrontation between old standards. It is more guided toward the construction of new objectives, policies, guidelines and methods of organization and communication at work than toward simple changes of the old.

Therefore, after the training activity, the professionals' understanding of PSE was clear and they were able to apply the learned subject in practice, improving the quality of activity execution.

\subsubsection{Contribution of training to their PSE professional practice}

After the training, the professionals involved with PSE were able to reflect on their practice and, based on that, confront ideas and experiences lived among the professionals, making an association with problems faced in practice. 
Training contributed a lot to my professional practice. Actually, to all school principals. Although it is a program that involves the health and education secretariats, we had never had training about the program. Today my knowledge increased, improving my professional practice within PSE, where I have a different viewpoint in certain situations with our students. (PRINCIPAL 9, our translation).

Now I understood better how to work with the program within the school. Nowadays I don't wait for the health team. What I can advance in the program, I do. And in every action I execute, I can reflect about the practice. This way, I feel like a professional who effectively carries out PSE. (PRINCIPAL 3, our translation).

Yes. Training helped me conduct my professional practice according to theoretical references discussed in training, and rethink them based on my lived experience in the program. (PRINCIPAL 4, our translation).

Training is necessary to qualify proactive professionals, able to draw reflections about their work and, also, with the ability to diagnose and solve problems, make decisions, intervene in the process, face situations in constant change (BRASIL, 2007).

School principals, in their reports, showed that after training they started to understand their role within PSE activities, being able to connect professional practice and PSE activities and reflecting about their practices. Today they have a different viewpoint in certain situations, giving necessary support to the students' health supervision.

\subsubsection{Contribution of training about PSE to the personal growth of the school principals}

The fourth item of the group interview asked the professionals who participated in the training whether it contributed to their personal growth. For personal growth, it is necessary to develop in each person the ability to interpret everyday life and act to incorporate adequate attitudes and/or behaviors to improve quality of life (BRASIL, 2011).

Every investment in personnel training and qualification, when well planned and developed, is able to produce positive change in people's performance, as the following reports show: 
Training showed us that we need to be much more humane and welcoming with students. And not only carry out PSE activities technically, to fulfill prescribed deadlines. Today I have a more humane viewpoint in actions with students. (PRINCIPAL 7, our translation).

When we shared knowledge and experiences with other professionals during training, I could reflect on my personal actions, when I could weave different knowledge, new ideas and paths for PSE. (PRINCIPAL 8, our translation).

Campos et al. (2006) consider humanization as a social and subjective process which results in the transformation of individuals and the expansion of their ability to act in relationships, as was identified in the reports of many professionals, as mentioned before.

According to the analysis of the reports presented by the school principals, training contributed positively to personal growth, because it increased and strengthened affective relations between those professionals. It stimulated reflective actions, constructing new knowledge and valuing the work with PSE. They learned the different aspects that encompass the program and its relevance, showing personal growth and adopting that knowledge in life.

\subsubsection{Suggestions for the training about PSE to be more resolute in what it proposes}

Trainings need to be planned in a context that allows professionals to input their contributions and gives them the opportunity to share the problems faced with PSE, the work strategies used and the solutions they find every day to better direct the actions.

The last item of the group interview asked the professionals about their suggestions to make training more resolute for the practice in PSE. Thus, the following suggestions were given:

I believe that PSE is a very broad program, because of that, training should be longer to discuss in detail all the matters proposed by the program. (PRINCIPAL 2 , our translation).

I think trainings about PSE should happen in the school environment, with principals, coordinators, teachers and students, to clearly understand the importance of PSE. (PRINCIPAL 7, our translation). 
It would be great if trainings about PSE reached a bigger number of principals. Because only ten principals participated in this one. Also, it would be good to have teachers participating, because many still don't have a clear idea of the program and think that actions should take place in an isolated way, without the joint participation of the health and education sectors. (PRINCIPAL 8, our translation).

Permanent training is paramount for school professionals, in addition to the need to hire professionals from different backgrounds, with the profile and skill set to carry out actions of health promotion (FERREIRA et al., 2014; MORORÓ, 2017).

Thus, we evidence through their reports that school principals had some suggestions, such as increasing the training course load to enable detailed discussion of all the matters proposed by the program. They also suggested adding principals from other schools and teachers. They mentioned that future trainings about PSE could take place in the school environment, so that the entire school staff, as well as students, could understand the importance of the program, since it can contribute to the decrease of sociocultural inequality (LARA, 2016) and the promotion of health.

\section{Final considerations}

During the study, we verified the profile of the research participants, diagnosed the participants' knowledge concerning PSE, detecting that school principals know of PSE, but still don't fully understand the meaning of the program's policy, indicating a need to educate these professionals. Thus, a training activity about the program characteristics was later carried out, followed by an analysis of the training process and finally the evaluation of the training process's contributions for those involved.

In this context, we analyzed the contributions that a training activity provided for PSE actions, starting with a reflection on reality, drafted and thought in terms of pedagogical simplicity for a better understanding by the target audience, structured to support professionals who began their PSE activities. In this perspective, the principals' participation in an action research generated critical reflection on their realities, after diagnosing the professionals' knowledge level concerning PSE characteristics. Thus, during this process, not only individual and collective knowledge was constructed, but 
also new abilities and attitudes that fostered resignifying values and transforming undesirable situations.

We also emphasize that training caused an active engagement between the researcher and the professionals, fostering shorter distances between them, concerning research that investigated causes and consequences for the resolution of several diagnosed problems. However, we highlight that it isn't enough to open spaces to promote health, it is necessary to offer training on PSE, so that professionals can develop abilities to handle health-illness processes, important to execute actions.

Therefore, investing in more PSE trainings contributes to transform professional, pedagogical and health practices to organize services, constituting an essential strategy to improve PSE actions.

\section{References}

BEGO, A. Políticas públicas e formação de professores sob a perspectiva da racionalidade comunicativa: da ingerência tecnocrata à construção da autonomia profissional. Educação \& Formação, Fortaleza, v. 1, n. 2, p. 3-24, 2016. Available at: https://revistas.uece.br/index.php/redufor/article/view/98. Access on: Mar. 20, 2020.

BRASIL. Caderno do gestor do PSE. Brasília, DF: Ministério da Saúde, 2015a.

BRASIL. Cadernos temáticos do PSE: práticas corporais, atividade física e lazer. Brasília, DF: Ministério da Saúde, 2015b.

BRASIL. Cadernos temáticos do PSE: saúde ocular. Brasília, DF: Ministério da Saúde, 2016.

BRASIL. Cadernos temáticos do PSE: verificação da situação vacinal. Brasília, DF: Ministério da Saúde, 2015c.

BRASIL. Decreto no 6.286, de 5 de dezembro de 2007. Institui o Programa Saúde na Escola - PSE, e dá outras providências. Diário Oficial [da] República Federativa do Brasil, Poder Executivo, Brasília, DF, 6 dez. 2007.

BRASIL. Instrutivo PSE. Brasília, DF: Ministério da Saúde, 2011.

BRASIL. Política Nacional da Promoção da Saúde. Brasília, DF: Ministério da Saúde, 2006. 
BRASIL. Portaria no 254, de 24 de julho de 2009. Estabelece diretrizes para a operacionalização do acesso às consultas oftalmológicas e o fornecimento de óculos, para a viabilização plena do Projeto Olhar Brasil e as disposições transitórias para a Ação Emergencial do PBA - Programa Brasil Alfabetizado. Diário Oficial [da] República Federativa do Brasil, Poder Executivo, Brasília, DF, 25 jul. 2009a.

BRASIL. Resolução no 466, de 12 de dezembro de 2012. Diretrizes e normas regulamentadoras de pesquisas em seres humanos. Diário Oficial [da] República Federativa do Brasil, Poder Executivo, Brasília, DF, 13 dez. 2012.

BRASIL. Saúde na escola. Brasília, DF: Ministério da Saúde, 2009b.

BRASIL. Triagem de acuidade visual manual de orientação. Brasília, DF: Ministério da Saúde e Ministério da Educação, 2008.

CAMPOS, E. F. et al. Os desafios atuais para educação permanente no SUS. In: BRASIL. Cadernos de RA. Saúde. Recursos Humanos em Saúde. Brasília, DF: Ministério da Saúde, 2006. p. 39-43.

CECCIM, R. B. Educação permanente em saúde: desafio ambicioso e necessário. Interface: Comunicação, Saúde, Educação, Botucatu, v. 9, n.16, p. 61-177, 2005. Available at: http://www.scielo.br/pdf/icse/v9n16/v9n16a13.pdf. Access on: Mar. 20, 2020.

FERNANDES, R. M. C. F. Educação permanente: uma dimensão formativa no Serviço Social. 2008. Tese (Doutorado em Serviço Social) - Programa de Pós-Graduação em Serviço Social, Universidade Católica do Rio Grande do Sul, Porto Alegre, 2008.

FERREIRA, H. S. Educação Física e saúde nas escolas públicas municipais de Fortaleza: uma proposta de ensino. Fortaleza: UECE, 2012.

FERREIRA, I. C. et al. Percepções de gestores locais sobre a intersetorialidade no Programa Saúde na Escola. Revista Brasileira de Educação, Rio de Janeiro, v. 19, n. 56, p. 61-76, 2014. Available at: http://www.scielo.br/pdf/rbedu/v19n56/v19n56a04.pdf. Access on: Mar. 20, 2020.

FIALHO, L. M. F.; SANTANA, J. R.; BRANDENBURG, C. La calidad de vida infantil y sus dimensiones: percepción de escolares. Barbarói, Santa Cruz do Sul, n. 45, v. 2, p. 227-241, 2015. Available at: https://online.unisc.br/seer/index.php/barbaroi/article/view/5065. Access on: Mar. 20, 2020.

FREIRE, P. R. N. A importância do ato de ler: em três artigos que se completam. 51. ed. São Paulo: Cortez, 2011.

LARA, A. M. Políticas de redução da desigualdade sociocultural. Educação \& Formação, Fortaleza, v. 1, n. 3, p. 140-153, $2016 . \quad$ Available at: https://revistas.uece.br/index.php/redufor/article/view/118. Access on: Mar. 20, 2020.

Educação \& Formação, Fortaleza, v. 5, n. 14, p. 195-215, maio/ago. 2020 
MINAYO, M. C. S. O desafio do conhecimento: pesquisa qualitativa em saúde. 12. ed. São Paulo: Hucitec: Abrasco, 2010.

MORORÓ, L. A influência da formação continuada na prática docente. Educação \& Formação, Fortaleza, v. 2, n. 4, p. 36-51, 2017. Available at: https://revistas.uece.br/index.php/redufor/article/view/122. Access on: Mar. 20, 2020.

RAMOS, L. S. et al. Estratégia de Roda de Conversa no processo de educação permanente em saúde mental. Revista Rene, Fortaleza, v. 14, n. 4, p. 845-853, 2013. Available at: https://www.redalyc.org/pdf/3240/324028459022.pdf. Access on: Mar. 20, 2020.

SANTOS, M. A.; FERREIRA, H.; SIMÕES, L. L. Saberes da docência aprendidos no Pibid: um estudo de caso com professores supervisores de Educação Física. Educação \& Formação, Fortaleza, v. 1, n. 2, p. 104-120, 2016. Available at: https://revistas.uece.br/index.php/redufor/article/view/103. Access on: Mar. 20, 2020.

THIOLLENT, M. Metodologia da pesquisa-ação. São Paulo: Cortez, 2011.

ZANCHA, D. et al. Conhecimento dos professores de Educação Física escolar sobre a abordagem Saúde Renovada e a Temática Saúde. Conexões, Campinas, v. 11, n. 1, p. 204-217, 2013. Available at: https://www.periodicos.sbu.unicamp.br/ojs/index.php/conexoes/article/view/8637638.

Access on: Mar. 20, 2020.

Karlla da Conceição Bezerra Brito Veras (Fortaleza, Ceará, Brasil)
Universidade Estadual do Ceará (UECE), Programa de Pós-Graduação em Saúde Coletiva,
Doutorado em Cuidados Clínicos em Saúde
Doctoral student of the Graduate Program in Clinical Care in Nursing and Health at UECE, master in
Health Education at UECE, presenting knowledge in the use of Active Methodologies in the classroom,
specialist in Obstetrics from the Metropolitan Faculty of Fortaleza (Fametro) and graduated in Nursing
from the University of Fortaleza (Unifor). Tendered at the Municipality of São Benedito-CE as a nurse
in the Family Health Strategy, where she worked as coordinator of the Health at School Program
(PSE) and Family Health Support Center (NASF) at the Municipal Health Secretariat of São Benedito-
CE between 2014 and 2017.
Authorship contribution: Prepared the introduction, methodology and data collection.
Lattes: http://lattes.cnpq.br/5269064271273231.
E-mail: karlla_veras@hotmail.com.

Educação \& Formação, Fortaleza, v. 5, n. 14, p. 195-215, maio/ago. 2020

DOI: https://doi.org/10.25053/10.25053/redufor.v5i14.898in

http://seer.uece.br/redufor 


\section{Heraldo Simões Ferreira (Fortaleza, Ceará, Brasil) \\ Universidade Estadual do Ceará (UECE), Programa de Pós-Graduação em Cuidados Clínicos em Enfermagem e Saúde, Curso de Mestrado e Doutorado em Educação}

He has been an adjunct professor at UECE since 2003. He is a professor in the Graduate Program in Education (PPGE) at UECE (master's and doctorate in Education), professor and vice-coordinator of the Professional Master's Course in Health Education (CMEPES) at UECE. Coordinates the undergraduate course in Distance Physical Education at UECE / UAB; the specialization in Martial Arts, Combat Sports and Fights from UECE; and the UECE Nucleus of Dances and Struggles extension project (Nudal). He is a 6th degree Karate black belt (CBK / FCK). He is the leader of the Group of Studies and Research in School Physical Education (Gepefe) at UECE. He is an advisor to the Regional Physical Education Council (CREF5).

Authorship contribution: Analyzed the data and carried out the final review.

Lattes: http://lattes.cnpq.br/4687823647729315.

E-mail: heraldo.simoes@uece.br.

Lídia Andrade Lourinho (Fortaleza, Ceará, Brasil)
Universidade Estadual do Ceará (UECE), Programa de Pós-Graduação em Saúde Coletiva,
Mestrado Profissional Ensino na Saúde
PhD in Public Health from UECE / UFC / Unifor and master in Health Education from Unifor.
Pedagogue, speech therapist and psychopedagogue. Researcher at the Health Laboratory in
Educational Spaces with a focus on Health Education and Health Training, linked to the PhD in
Collective Health at the University of Fortaleza (Unifor). Doctoral scholarship from the Ceará
Foundation for Support to Scientific and Technological Development (Funcap).
Authorship contribution: Presented the discussion of the results.
Lattes: http://lattes.cnpq.br/6662326867963958.
E-mail: lidiandrade67@gmail.com.

Responsible publisher: Lia Machado Fiuza Fialho Ad hoc experts: Gustavo Cunha de Araújo e Cristine Brandenburg

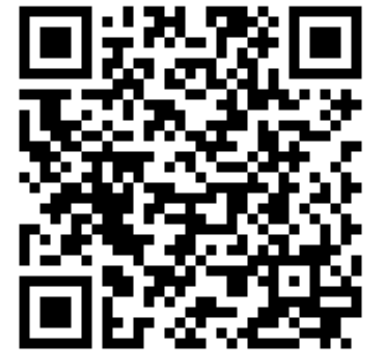

Received on January 9, 2019.

Accepted on July 25, 2019. 